\title{
Attacking Punitive Retribution at Its Heart - A Restorative Justice Thrust
}

\author{
Theo van Willigenburg | ORCID: 0000-0002-1917-1016 \\ Research Fellow Vrije Universiteit Amsterdam - Faculty of Religion \\ and Theology \\ vanwilligenburg@kantacademy.nl
}

\begin{abstract}
Eduardus Van der Borght | ORCID: 0000-0002-9154-194X
Desmond Tutu chair vu University Amsterdam - Faculty of Religion and Theology, Extraordinary Professor Systematic Theology Stellenbosch University - Faculty of Theology

eajg.vander.borght@vu.nl
\end{abstract}

\begin{abstract}
Restorative justice, aimed at restoring human relations instead of just punishing offenders, is often defended with reference to biblical values like reconciliation, forgiveness, and mercy. Advocates of retributivism, which is the philosophy that underlies the practice of punishing perpetrators with the sole goal of inflicting hardship on them, regularly ridicule such defenses. In response we will not directly defend restorative justice, but critically inquire in the main theoretical arguments with which advocates of retributivism seek to rationalize their view. We point out the weaknesses of these arguments and why we believe that restorative procedures can do much better in serving the goals of (criminal) justice.
\end{abstract}

\section{Keywords}

restorative justice - retributivism - justification of punishment - forgiveness - mercy 
Against a dominant culture which favors punitive retribution (leading in the United States to the mass incarceration of alleged criminals ${ }^{1}$ ) advocates of restorative justice try to establish procedures that enhance reconciliation and rehabilitation instead of simple punishment. Many of the original theorists of restorative justice speak from a Christian background, like Howard Zehr, ${ }^{2}$ Christopher Marshall, ${ }^{3}$ Thomas Noakes-Duncan ${ }^{4}$ and Daniel W. Van Ness. ${ }^{5}$ And many supporters and practitioners of restorative procedures do so motivated by their religious beliefs. Zehr sees biblical justice as shalom, that is as serving the wholeness and peace of the community, and therefore as restorative and not retributive. ${ }^{6}$ Marshall has expanded and deepened Zehr's work on the biblical worldview of justice by arguing that justice is satisfied not by retributive punishment but by repentance, restoration and renewal. ${ }^{7}$ In his Beyond Retribution Marshall argues that the New Testament conception of justice (diakosune) is continuous with the Hebrew conception of righteousness (sedaqah) which is intentionally restorative. ${ }^{8}$ Noakes-Duncan has asserted that the biblical understanding of justice in early Christianity formed the basis of an ecclesial practice of seeking 'peace and reconciliation between people and their communities, who have suffered relational injury', because of wrongdoing. ${ }^{9}$ Van Ness has worked for long in implementing such a practice into the reality

1 See Mary D. Looman and John D. Carl, A Country Called Prison. Mass Incarceration and the Making of a New Nation (Oxford: Oxford University Press, 2015). The United States is the Western country with the most severe punitive culture (Bruce Western, Punishment and Inequality in America (New York: Russell Sage Foundation, 2006), p. 11). America is the world leader in incarcerating citizens. 700 people out of every 100,000 are imprisoned (India 32, Russia 469, China +/- 300; more than half of all countries have rates below 150 per 100,000). At this moment in time the United States has 2,210,0oo inhabitants behind bars, in a population of 325,000,000. See World Prison Population List of the International Center for Prison Studies (King's College London): www.prisonstudies.org (last accessed on o8-11-2018).

2 Howard Zehr, The Little Book of Restorative Justice, (Intercourse: Good Books, 2002), pp. 5-7.

3 Christopher D. Marshall, The Little Book of Biblical Justice: A Fresh Approach to the Bible's Teaching on Justice, (Intercourse: Good Books, 2005).

4 Thomas Noakes-Duncan, Communities of Restoration. Ecclesial Ethics and Restorative Justice, (London: T\&T Clark, 2017).

5 Daniel W. Van Ness and Karen Heetderks Strong, Restoring Justice, 3rd edn (Cincinnati: Anderson, 2006), pp. 14-18.

6 Howard Zehr, Changing Lenses: A New Focus for Crime and Justice (Scottdale: Herald Press, 1990), pp. 126-57.

7 Christopher D. Marshall, The Little Book of Biblical Justice, pp. 28-41.

8 Christopher D. Marshall, Beyond Retribution: A New Testament Vision for Justice, Crime, and Punishment, Studies in Peace and Scripture (Grand Rapids: Eerdmans, 2001), p. 47.

9 Thomas Noakes-Duncan, Communities of Restoration, p. 9. 
of the criminal justice system, through the provision of restorative justice Bible studies for professionals working with incarcerated offenders. ${ }^{10}$

Because of contributions like these there is a growing interest in integrating restorative procedures in the criminal justice system. Even so, the truth is that restorative justice as a philosophy and movement of reform still only plays a fairly marginal role in criminal justice. Retributivism, which is the conception of justice that underlies the practice of 'giving offenders their due' is dominant in the public opinion. Although advocates of restorative justice have in many ways criticized retributivism, ${ }^{11}$ unfortunately they only sparsely have addressed the philosophical arguments with which retributivists rationalize their own view. A thorough criticism of retributivism on a theoretical level seems to be lacking. Prominent spokesmen of retributivism like Michael Moore, Anthony Duff and Andrew von Hirsch have written lengthy warnings against the restorative paradigm though. ${ }^{2}$ Moore even ridicules those who support restorative justice with religious arguments by characterizing Jesus' protests against the stoning of an adulteress as a 'pretty clumsy moral philosophy' ${ }^{13}$ It is time for a counter-argument.

10 Daniel W. Van Ness, 'Prisons and Restorative Justice', in Gerry Johnstone and Daniel W. Van Ness, eds, Handbook of Restorative Justice, pp. 312-24 at p. 321.

11 Lode Walgrave, 'Imposing Restoration instead of Inflicting Pain', in Andrew von Hirsch, Julian V. Roberts and Anthony E. Bottoms, Restorative Justice and Criminal Justice: Competing or Reconcilable Paradigms?, Studies in Penal Theory and Penal Ethics (Oxford and Portland: Hart, 2003), pp. 61-78. See also Christopher D. Marshall, Beyond Retribution, pp. 112-131. Marshall points out the practical problems in applying retribution, like how to ensure proportionality which not only requires 'the ability to rank crimes in terms of their seriousness' but also the ability to determine 'what constitutes a commensurate punishment for a specific crime' (pp. 113-114). Marshall criticizes the exaggerated focus on individual responsibility in retributivism (ignoring social conditions) and its unjustified contention that 'punishment is intrinsically necessary to the expression of opprobrium' (pp. 115-119).

12 See Andrew von Hirsch, Andrew Ashworth and Clifford Shearing, 'Specifying Aims and Limits for Restorative Justice: A “Making Amends" Model?' in: Andrew von Hirsch, Julian V. Roberts, and Anthony E. Bottoms, Restorative Justice and Criminal Justice: Competing or Reconcilable Paradigms?, Studies in Penal Theory and Penal Ethics (Oxford and Portland: Hart, 2003), pp. 21-42. Anthony Duff, 'Responsibility, Restoration, and Retribution', in: Michael Tonry ed, Retributivism Has a Past: Has It a Future?, (Oxford: Oxford University Press, 2011), pp. 63-85. Duff has argued against the restorative justice philosophy that 'the kind of restoration that crime makes necessary can (given certain deep features of our social lives) be brought about only through retributive punishment.' Anthony Duff, 'Restoration and Retribution', in Andrew Von Hirsch, Julian V. Roberts, and Anthony E. Bottoms, Restorative Justice and Criminal Justice: Competing or Reconcilable Paradigms?, Studies in Penal Theory and Penal Ethics (Oxford and Portland: Hart, 2003), pp. 43-6o.

13 Michael S. Moore, Placing Blame: A Theory of Criminal Law (Oxford: Oxford University Press, 1997), p. 188. 
We contend that theology has a responsibility in publicly addressing and criticizing the way influential criminologists, legal theorists and other opinion makers try to rationalize punitive retribution as 'right' and 'just'. Such an address should take a form that is accessible to the theologically uninformed public. ${ }^{14}$ Our arguments will make sparse use of biblical-theological or dogmatic ideas. The intention is not to directly defend restorative justice as a theory and practice, but rather to point out the serious weaknesses of the seemingly appealing arguments and theories with which retributivists advocate for that point of view.

This article distinguishes and analyzes five of such theories: its goal is to contribute to the theoretical discussion between retributive and restorative justice. It is important to do so as there is always the danger that restorative justice becomes 'preoccupied with process and technique'.15 The intention is also to consider the relationship between arguments mounted against retributivism and a biblical and theological understanding of justice. Marshall has warned that when theological insights are translated into secular categories there is a danger that 'what is most distinctive and essential to the Christian worldview is filtered out.'16 We believe however that many elements of a Christian anthropology and a Christian view of the character of human communities can be made plausible in secular terms. Christianity's alternative interpretation of reality that competes with the story of the liberal secularism that underlies retributivism need not be convincing only to believers.

\section{Restorative Justice and Retributivism}

Restorative justice is a term referring to a set of theories and practices that are critical of the existing criminal justice system and the retributivist philosophy. Although there is no fixed definition of restorative justice (it is an ambiguous

14 Marshall holds that 'Christians should at least encourage the legal system to establish procedures that are consistent with and that move in the direction of the personal and relational values expressed in Jesus' call to forgiveness and love of the enemy'. These procedures, so he contends, 'may be commended to government bodies on pragmatic, even financial grounds'. Marshall, Beyond Retribution, p. 23. We would add that restorative procedures can also be recommended by showing how the philosophy behind the dominant retributive procedures fails.

15 Geoff Broughton, 'Restorative Justice: Opportunities for Christian Engagement', International Journal of Public Theology 3 (2009), pp. 299-318.

16 Christopher D. Marshall, All Things Reconciled, (Eugene: Cascade Books, 2018), p. 72. 
concept $\mathrm{t}^{17}$ ) most of the theories and practices involved have at least the following characteristics.

(1) Restorative justice understands transgressions and crimes not primarily as a violation of rules, but as a violation against persons and human relations. ${ }^{18}$ Transgressions are regarded as conflicts that need to be given back to their rightful owners to resolve: offenders/victims and their communities. ${ }^{19}$

(2) Restorative justice therefore gives primary attention to the needs of the injured persons involved: first the victim and the related community and second the perpetrator and related community. It seeks 'the liberation of the victims from being just victims as well as the liberation of the offender from being just an offender, and liberating the community from their infliction in guilt'.20

(3) Restorative justice procedures are based on values like non-domination, empowerment of victims, respectful listening, equal concern for all stakeholders, and accountability. ${ }^{21}$

(4) Restorative justice does not regard sentence and punishment as the crucial criteria in order to establish justice. Instead it aims in Victim-Offender Mediation programs at a constructive dialogue between victims, offenders, and their communities, seeking to identify responsibilities and obligations, to meet needs and to promote healing and dignity.

Restorative justice thus aims at the healing of victims, offenders and communities that have been injured by crime and requires active involvement of them

17 'Over the last two decades, Restorative Justice has emerged in varied guises with different names, and in many countries; it has sprung from sites of activism, academia, and justice system workplaces. The concept may refer to an alternative process for resolving disputes, to alternative sanctioning options, or to a distinctively different, new model of criminal justice organised around principles of restoration to victims, offenders and the communities in which they live.' Kathleen Daly and Russ Immarigeon, 'The Past, Present, and Future of Restorative Justice: Some Critical Reflections', Contemporary Justice Review, 17 (1998), 21-45, p. 21.

18 Howard Zehr, Changing Lenses. Restorative Justice for Our Times (Harrisonburg, Virginia: Herald Press, 1990/ 2015), 5, 64-69. Howard Zehr, 'Justice as Restoration, Justice as Respect', The Justice Professional, 11 (1998), pp. 71-87.

19 Nils Christie, 'Conflicts as property', British Journal of Criminology, 17 (1977), 1-15.

20 Fernando Enns, God's Justice and Human Justice. Theological Challenges of Speaking about God's Last Judgment And some Ethical Implications, unpublished manuscript Vrije Universiteit (2016).

21 John Braithwaite, 'Principles of Restorative Justice', in Andreas von Hirsch, Julian V. Roberts, Anthony E. Bottoms, Kent Roach, Mara Schiff, eds., Restorative Justice and Criminal Justice: Competing or Reconcilable Paradigms (Oxford: Hart Publishing, 2003), pp. 1-20. 
in the justice process 'as early and as fully as possible.'22 It covers a wide set of practices. These do not necessarily exclude punishment of offenders, because trial, conviction, and punishment may be part of the whole restorative process. But punitive retribution is never regarded as the ultimate goal and justification of inflicting hardship upon the perpetrator. Restorative justice advocates refuse to believe that justice can be done by adding suffering (of the perpetrator) to suffering (of the victim).

Retributivism, however, is the contention that offenders should suffer solely because they deserve hardship as punishment for their wrongful acts. Usually this positive claim is distinguished from a negative one: those that do no wrong may not be punished or in other ways be addressed by the criminal justice system (a negative claim that is endorsed by most advocates of restorative justice). Here we focus our theoretical response on the positive claim. Although many varieties of positive retributivism may be distinguished, ${ }^{23}$ most retributive theorists will support the following four claims.

(1) We are obliged to punish those who have been found to commit an offence. Punishment here is understood as the intentional imposition of some cost or burden (or at least the withdrawal of benefits) in response to a wrong done by the perpetrator, sending a message of condemnation. ${ }^{24}$

(2) The offender's desert is a sufficient reason for punishing them. ${ }^{25}$ No other reason is needed. Justice is defined in terms of rebalancing the scales by inflicting punishment as an answer to wrongdoing.

(3) The hardship involved in punishment should therefore be proportionate in severity to the seriousness of the offense. Proportionality is the essence of justified retribution. ${ }^{26}$

(4) Securing the perpetrator's desert is a value that outweighs all other moral considerations - for example, about mercy or about rehabilitation. ${ }^{27}$ Punishing the perpetrator thus has a positive value apart from any

22 Daniel W. Van Ness and Gerry Johnstone, 'The Meaning of Restorative Justice', in Gerry Johnstone and Daniel W. Van Ness, eds, Handbook of Restorative Justice (Cullompton and Portland: Willan Publishing, 2007), pp. 5-23.

23 John Cottingham, 'Varieties of Retribution', Philosophical Quarterly, 29 (1979), 238-46.

24 Anthony Duff, 'Relational Reasons and the Criminal Law', in: L. Grees \& B. Leiter, Oxford Studies in Philosophy of Law: Volume 2 (2013), 175-210.

25 Anthony Duff, 'Legal punishment', In: E. N. Zlata ed., The Stanford encyclopedia of philosophy 2008, <http://plato.stanford.edu/archives/fall2oo8/entries/legal-punishment> [accessed 1 March 2019].

26 Andrew von Hirsch, Censure and Sanctions (Oxford: Oxford University Press, 2003), esp. chapter 2 .

27 Michael S. Moore, Placing Blame, pp. 40-43. 
consequences that may follow upon such punishment (for instance, the effect of special or general deterrence).

Most restorative justice advocates strongly oppose these desert-oriented claims. This does not necessarily mean that they completely reject the criminal justice system (though some hold that the system is fundamentally flawed and should be replaced by a restorative scheme ${ }^{28}$ ). Restorative justice is concerned with what happens after a perpetrator's guilt has been established. Before restorative procedures can be applied we need the police and other officials to inquire a crime. By officially investigating a case the state empowers individuals to seek and obtain acknowledgment for wrongs committed to them. It is often only after judicial adjudication of guilt, that restorative procedures like mediation, conferencing circles, and panels may be applied. Such procedures can be combined with imprisonment or other sanctions, as it may be necessary to incapacitate dangerous perpetrators, in order to protect (potential) victims. Such deterrent or incapacitating back-up sanctions could be part of restorative justice practices. ${ }^{29}$ Sanctions, like imprisonment, may also be applied in order to encourage perpetrators to comply to restorative procedures. ${ }^{30}$ Finally, in restorative processes perpetrators can be asked to make amends that may also be burdensome to them (just as sincere regret and apologies may be difficult for them $\left.{ }^{31}\right)$. But the hardship of such painful obligations is never vindictive or retributive.

Advocates of restorative justice oppose the idea that justice may require punishment simply for the sake of punishment. Taking 'just desert' as the

28 E.g. Lode Walgrave, 'Imposing Restoration Instead of Inflicting Pain', in: Andrew von Hirsch (et al.), Restorative Justice and Criminal Justice: Competing or Reconcilable Paradigms?, Studies in Penal Theory and Penal Ethics (Oxford and Portland: Hart, 2003), pp. $61-78$.

29 John Braithwaite, 'Restorative Justice: Assessing Optimistic and Pessimistic Accounts', Crime and Justice, Vol. 25 (1999), 1-127, pp.

30 Though there are advocates of restorative justice who argue that prisons and restorative justice are mutually exclusive, see for instance Odillo Vidoli Guidoni, 'The ambivalences of restorative justice: Some reflections on an Italian prison project', Contemporary Justice Review, 6 (2003), 55-68. And some even reject the inclusion of any coercive sanctions within the restorative frame, because they deem punitivity and restorative justice incompatible, see Peter McCold, (200o) 'Toward a Holistic Vision of Restorative Juvenile Justice. A Reply to the Maximalist Model', Contemporary Justice Review 3 (2000), pp. 357-414. For a more nuanced approach see Daniel W. Van Ness, 'Prisons and restorative justice', In G. Johnstone \& Daniel W. Van Ness, eds., Handbook of restorative justice (Devon, UK: Willan, 2007), pp. 312-324.

31 Christopher Marshall speaks about "the pain of taking responsibility" (as part the realization of God's restorative justice in the New Testament). Marshall, Beyond Retribution, pp. 132-140. 
prime criterion for doing justice will not lead to the healing of victims, offenders and communities that have been injured by crime, even when victims ask for 'revenge'. Retributive justice simply is defective in elevating human dignity, transforming people and healing traumas caused by crime. What are the arguments then with which advocates of retributivism rationalize their views?

\section{$3 \quad$ Fair Play and Trust}

An appealing one is the Fair Play argument which says that we need to impose hardship on offenders in order to re-balance the distribution of benefits and burdens which is upset by the criminal offence. ${ }^{32}$ The idea is that it is to our mutual benefit that we live together in a society, but doing so requires that we accept certain limits on our behaviour (for example, not interfering with others, use violence or steal property). If a person fails to exercise such selfconstraint, he - as Herbert Morris phrased it - 'renounces a burden others have voluntarily assumed and thus gains an advantage which others, who have restrained themselves, do not possess. ${ }^{33}$ This unfair advantage has to be erased by punishing the 'free rider', thus 'exacting the debt' he has to other citizens and thereby restoring the balance of justice. So the idea is that a criminal has the double advantage of not obeying the law while enjoying the advantages of the rule of law, thanks to his law-abiding fellow-citizens. Punitive retribution is meant to restore the balance of benefits and burdens. Such re-balancing makes the hardship imposed on offenders 'fair'.

Attractive as this justification of retribution from fairness at first sight may be, it is much too one-sided to really gain argumentative weight. The logic of the argument imagines that the greater the imbalance of benefits and burdens the more serious the crime and the more severe the punishment should be. But fraud may produce a much greater advantage than manslaughter, though the latter is usually regarded as the more serious crime. In general, the seriousness of crimes like murder or manslaughter cannot be explained in terms of free riding and a lack of fair play. Most people who violently abuse or murder someone are not deliberately renouncing a burden that others would like to renounce too, though they refrain from doing so. It is ill conceived to regard murder as a form of free riding. Such a view seriously distorts the essential character of crime. The wrongfulness of rape or murder does not consist in taking an 'unfair advantage'. The rapist or murderer does not wrong society by 'not

32 Michael Davis, M. 'How to Make Punishment Fit the Crime', Ethics, 93 (1983), 726-752.

33 Herbert Morris, 'Persons and Punishment', The Monist 52 (1968), 475-501 at 483. 
playing fair'. He does seriously wrong the victim by violating a person's bodily integrity and taking her life. ${ }^{34}$

The basic problem of the fair play theory, even from a secular point of view, is that it pictures society as a project of cooperation for mutual advantage, thereby reducing civic interrelation to interactions between rational egoists. There is much more at stake between civilians than rational interest. In a complex society people need to trust each other in a very basic way, and this is a kind of trust that is not based on considerations of fairness ('you will be fair to me if I will be fair to you'). With most co-civilians we only have temporally limited interactions with no iterated encounters that might create possibilities for weighing burdens against benefits. We simply need a system that helps to maintain conditions of basic trust in a society - that is, 'trust in each other, in the first instance, and trust in the legal system itself as an institution designed to maintain trust secondarily'. ${ }^{35}$ Trust theory seems better suited to justify retribution. Offenders who commit a crime demonstrate a lack of trustworthiness, because of their willingness to violate the conditions of basic trust in society. That is the reason why they deserve punishment.

Even so, one may question why a display of untrustworthiness merits the hardship involved in punishment. Advocates of trust theory hold that punishment is necessary to reaffirm for the members of the community the commitment to basic trust:

Those who commit offenses demonstrate that the ability of the law to maintain the conditions of trust in the community is not complete; punishing the criminal, however, serves to reestablish that trust and demonstrates that individuals need not adopt recourse to anticipatory violence as a means of protecting their interests against those who are willing to harm them. ${ }^{36}$

But why would the state (as the agent of the community) need to impose violence by punishing trespassers in order to demonstrate its ability to maintain trust in society? We doubt that the violation of the conditions of basic trust in the community can be properly remedied by the imposition of punishment

34 James G. Murphy, who was an early adherent of the Fair Play theory, later has embraced this criticism as others have done too. See James G. Murphy, 'Marxism and Retribution', Philosophy and Public Affairs, 2(1973), 217-243. See also Andrew von Hirsch, 'Proportionality in the Philosophy of Punishment: From "Why Punish?" to "How Much?", Criminal Law Forum, 1 (1990), 259-29o, at 264-269.

35 Susan Dimock, 'Retributivism and Trust', Law and Philosophy, 16 (1997), 37-62 at 44.

36 Dimmock, 'Retributivism and Trust', 54. 
upon the offender. Why not engage in procedures that are meant to directly foster trust and interpersonal reliance? Restorative justice promotes trust through a constructive dialogue between victims, offenders, and their communities, seeking to promote healing and reliance. The procedures of a restorative are not only much better suited to enhance self-assurance and trust in victims and their peers. ${ }^{37}$ They may also serve to give offenders a 'human face', thus diminishing nightmarish caricaturing among the public that might produce insecurity and fear. ${ }^{38}$ Restorative justice is probably much more suited to restore conditions of trust than punitive retribution. It also avoids a problem that is inherent if one recommends retributive punishment as the best way to restore the conditions of trust: how would it ever be possible to determine what proportion of punishment is needed to restore specific breaches of trust?

What is even more troublesome is the following question: how do we determine what kind of trust violations should be punishable? There are a great many violations of trust, among people of varying degrees of intimacy, that are not illegal (and should not be). Infidelity is considered by the betrayed partner as a serious breach of trust, but it would be absurd to make it into a punishable offense. The Trust theory has not only hardly an answer to the problem of proportionality of punishment. It stands even weaker in solving the problem of distinguishing punishable from non-punishable trust violations. ${ }^{39}$

It is perhaps possible for these problems to be handled by regarding the infliction of punishment not as a way of restoring basic trust, but as a forceful way of communicating society's censure of criminal offences. According to Antony Duff the authority of the law lies in its power 'to call alleged wrongdoers to public account, to judge their conduct, and to condemn and punish their criminal wrongdoing. ${ }^{40}$ This calling to public account must include judgment and

37 Theo van Willigenburg, 'Restorative Justice as Empowerment: How to Better Serve the Goals of Punitive Retribution', The International Journal of Restorative Justice, 1:2 (2018), 275-291.

38 Stephen P. Garvey, "Restorative Justice, Punishment, and Atonement', Utah Law Review, 1 (2003), 303-317.

39 Daniel Korman, 'The Failure of Trust-Based Retributivism', Law and Philosophy, 22 (2003), 561-575.

40 Anthony Duff, 'Relational Reasons and the Criminal Law', in Leslie Green and Brian Leiter, Oxford Studies in Philosophy of Law: Volume 2, (Oxford: Oxford University Press 2013), pp. 175-210, p. 18 o. 
punishment. Such punishment, understood as the imposition of something burdensome on the perpetrator, does not have the simple goal of making the guilty suffer. The goal is to communicate public censure. This action has at least two functions. First, it conveys to victims the acknowledgment that they have been wronged. As fellow citizens we owe it to victims that we notice and care about what they have suffered. And secondly, public censure makes clear that a society takes the rule of law and the values that have been infringed seriously, 'for to be committed to a value is to be committed to taking note of its violation'.41

The question however is why penal hard treatment is needed to successfully communicate society's censure. Why would the infliction of punishment be necessary? Mark that punishment, as Duff understands it, involves 'the imposition of something that is burdensome independently of its censorial meaning.'42 Restorative procedures are usually burdensome for offenders, morally, psychologically, and economically. But there is no burden involved independently of what serves acknowledgment of wrongfulness, recognition of victims and reconciliation between parties. Duff however, argues that the burden of hard treatment is necessary to induce in the offender 'a properly repentant understanding of what he has done'.43 Burdensome punishment makes it 'harder for the offender to ignore the message that punishment communicates'. A penitential suffering would provide for an adequate moral reparation for the wrong that was done, at least something that costs more than an apology.

Even so, arguing that penal retribution will induce a repentant consciousness in offenders conveys an unfounded psychology that in the past has inspired many forms of inhuman treatment of prisoners, like years of solitary confinement with nothing else to read than a Bible or forced labor to teach prisoners 'discipline'. Solitary confinement drives prisoners crazy instead of turning them into repentant sinners. And hard treatment, like forced labor, has hardly ever resulted in moral conversion and rehabilitation, let alone in sincere motions of apology. Hard treatment rather results in bitterness and a hardening of the heart.

Duff argues that it is no problem if apologies or expressions of remorse by the perpetrator are insincere, because for the public what matters is that the

41 Anthony Duff, 'Responsibility, Restoration, and Retribution', in Michael Tonry, ed, Retributivism Has a Past: Has It a Future? (Oxford: Oxford University Press, 2011), pp. $63-85$ at p. 72 .

$42 \quad$ Ibid., p. 78.

43 Ibid. 
ritual of holding to account the offender is undertaken. ${ }^{44}$ That is why public trials are important and why convictions to penal suffering are the most appropriate way to communicate public censure.

Yet, what good does this bring to victims? What good does the recognition of their suffering by the public bring them, if the offender who has wronged them gives them a dishonest apology and a crooked defense? The encounter between perpetrators and victims in restorative justice processes will bring victims much more in terms of recognition, clarification (what has happened? why me?), and regained self-respect (looking the offender in the eyes and personally calling him to account). A sincere apology, an honest explanation, and the opportunity for the victim to speak up for herself are infinitely more valuable than a formal, public condemnation of what the perpetrator has done.

\section{$5 \quad$ Vindication of Victims}

It can be argued that, although punitive retribution may not be the most ideal way of communication with perpetrators, it may bring victims more than just the formal solidarity and recognition by their fellow citizens (formal because mediated by a criminal trial). Jean Hampton has convincingly shown that punishment in some way vindicates victims by defeating wrongdoers. Crime does not just cause harm, like a loss of possessions, psychological distress and longterm feelings of insecurity. For victims the symbolic meaning of crime often is more important: they have been wronged by the perpetrator who has wrongfully invaded their house, damaged their property or caused physical injury. Much of the sting of being harmed derives from the identity implication of the crime. To be taken advantage of, exploited or hurt is resented because it implies that one is the sort of person who can be taken advantage of, exploited or hurt. 45

I have value equal to that of my assailant, then that must be made manifest after I have been victimized. By victimizing me, the wrongdoer has declared himself elevated with respect to me, acting as a superior who is permitted to use me for his purposes. [] [R]etributive punishment is the defeat of the wrongdoer at the hands of the victim (either directly or

\footnotetext{
44 Ibid., p. 79 .

45 'Disrespect begets disrespect', claims Howard Zehr, and few things communicate disrespect as effectively as the criminal exploitation of another human being. Howard Zehr, 'Justice as Restoration, Justice as Respect', p. 89.
} 
indirectly through an agent of the victim, e.g. the State) that symbolizes the correct relative value of wrongdoer and victim. It is a symbol that is conceptually required to reaffirm a victim's equal worth in the face of a challenge to it. ${ }^{46}$

Retribution is thus sought for because it may have a function in restoring the victim's self-image and dignity. This is the reason why victims are not content with a mere compensation (if possible) that restores the status quo (stolen goods are returned, damages are paid for). The violation they have experienced has not only material, but also (and often predominantly) symbolic meaning. This is confirmed in empirical research. ${ }^{47}$ Victimization means that the offender has violently appropriated status and power over the victim and the wider community. ${ }^{48}$ Punishing an offender may then serve the victim in three ways: ${ }^{49}$

(1) it restores the victim as an active actor (autonomy): she is no longer (just) a passive sufferer;

(2) it restores the victim's prestige (status) by degrading and disempowering the offender;

(3) it gives the victim voice as defender of the values that she and the offender are supposed to share..$^{50}$

If victimization means loss of dignity then the urge for retribution and 'getting the perpetrator back' might best be understood as an attempt to regain agency and dignity: 'The lord must be humbled to show that he isn't the lord of the victim. 51

Even so, punitive retribution is a notoriously indirect and inefficient way of annulling the affront that the victim has experienced. It is not difficult to see that restorative processes are much more effective and efficient in restoring the dignity and autonomy of victims. Because restorative justice sees crime as an issue of relationships it promotes practices that directly foster the

46 Jeffrie G. Murphy and Jean Hampton, Forgiveness and Mercy, (Cambridge: Cambridge University Press, 1988).

47 Kenworthey Bilz, 'Testing the Expressive Theory of Punishment', Journal of Empirical Legal Studies, 12 (2016), 358-392.

48 Tyler G. Okimoto and Michael Wenzel, 'The Symbolic Meaning of Transgressions: Towards a Unifying Framework of Justice Restoration', Karen Hegtvedt and J. Clay-Warner, eds, Advances in Group Processes (Bingley: Emerald, 2008), pp. 291-326. van Willigenburg, 'Restorative Justice as Empowerment', 281.

$50 \quad$ Michael Wenzel, Tyler G. Okimoto, Norman T. Feather and Michael J. Platow, 'Justice through Consensus: Shared Identity and the Preference for a Restorative Notion of Justice', European Journal of Social Psychology, 40 (2010), 909-930.

Murphy and Hampton, Forgiveness and Mercy, p. 126. 
restoration of interpersonal respect and worth..$^{52}$ Restoration processes may be profoundly empowering because victims can exercise much more control than in regular criminal procedures. Victims can be 'agents' instead of 'patients'. ${ }^{53}$ They may have the opportunity to face the offender in a safe environment and can say what they want to say, ask questions for further information, and enter into a dialogue about values. It appears that victims who participate in Victim-Offender Mediation programs have a much better sense of being heard and acknowledged than in the context of criminal justice procedures where they are often only heard as witness. ${ }^{54}$ Victims feel validated when offenders are able to offer an apology, ${ }^{55}$ but even when this result does not obtain they experience their active role and the respectful treatment by the mediator and others involved as distinctively empowering ${ }^{56}$ These procedures of restorative are also much better suited to reach clarification than the adversarial practices in retributive procedures (like interrogations in court). Entering into a dialogue with the offender is not only a matter of getting the answers for the sake of knowing the answers. Simply receiving some response ultimately fosters a feeling of acknowledgement, which is conductive to dignity. ${ }^{57}$ In general, for victims the restorative procedure itself is more important than the outcome.

A restorative justice process is a much better way of making sense of the victimizing event. It serves victims in acquiring autonomy, dignity and standing as active agents in their case, sometimes accompanied by painful emotions in case of testimonies, and as initiators of reflection and action with regard to the moral values at stake. Not retributive punishment but restorative justice procedures are the prime way of promoting the vindication of the victim. This does not preclude that restorative justice procedures may be painful for the perpetrator, because of the hardship of moral condemnation, loss of standing, and particular reparative obligations. But such hardship is not the aim of

$5^{2}$ Zehr, 'Justice as Restoration, Justice as Respect', John Braithwaite, Restorative Justice and Responsive Regulation (New York: Oxford University Press, 2002).

53 Lois Presser and Cynthia A. Hamilton, 'The Micropolitics of Victim-Offender Mediation', Sociological Inquiry, 16 (2006), 316-342.

54 Jo-Anne Wemmers and Katie Cyr, 'What Fairness Means to Crime Victims: A Social Psychological Perspective on Victim-Offender Mediation', Applied Psychology in Criminal Justice, 2 (2006), 102-128.

55 Jung Jin Choi, Dina L. Green, and Stephen A. Kapp, 'Victimization, Victim's Needs, and Empowerment in Victim Offender Mediation', International Review of Victimology, 17 (2010), 269-29o.

$5^{6}$ Nathan Harris, Lode Walgrave and John Braithwaite, 'Emotional Dynamics in Restorative Conferences', Theoretical Criminology, 8 (2004), 191-210.

57 Tom R. Tyler, 'Psychological Models of the Justice Motive: Antecedents of Distributive and Procedural Justice', Journal of Personality and Social Psychology, 67 (1994), 850-863. 
restorative justice as it is in punitive retribution. Punishment for the sake of making the offender suffer so that he may be humiliated and the victim dignified is not the appropriate way to vindicate victims.

\section{Kantian Theory}

But perhaps punitive retribution is not so much needed to vindicate the victim, but to acknowledge the responsibility and related status of the offender as a moral agent. By calling the transgressor to account we treat him as a responsible fellow member of the moral community. ${ }^{58}$ In other words we treat him as an agent and not as a patient, that is as someone who cannot be held responsible because of a psychic illness or mental handicap which has driven him to break the law. Retributivism would then be a way of acknowledging the status of perpetrators as morally responsible autonomous agents, and thus as a way of upholding the dignity of wrongdoers. ${ }^{59}$

This argument is at home in Immanuel Kant's theory of criminal justice in the second part of his Metaphysics of Morals: here he discusses the Right of the State under the theme of Public Right. ${ }^{60}$ According to Kant retributive punishment 'must always be inflicted upon him [the transgressor] only because he has committed a crime. For a human being can never be treated merely as a means [] his innate personality protects him from this []'.61 Punishment inflicted upon a perpetrator because this may deter him or others from future transgressions would mean that the transgressor is treated as a means in order to enhance public safety. According to Kant, all forward looking purposes of crime (prevention, rehabilitation) involve a profound disregard of the dignity of the criminal. He can only be treated as an autonomous agent with rational dignity if the punishment is solely an acknowledgment of his responsibility and an answer to his criminal acts. Any criminal should therefore submit himself to the retributive consequences of his deeds. For, says Kant, he has consented to his own punishment because of his consent to the very rules which he has broken work: 'Saying

\footnotetext{
$5^{8}$ Anthony Duff, 'Relational Reasons and the Criminal Law', p. 196.

59 Karen Baehler, 'Justifying Restorative Justice', in Gabriele Maxwell and James H. Liu, eds, Restorative Justice and Practices in New Zealand: Towards a Restorative Justice (Wellington: Institute of Policy Studies, 2007), pp. 289-299 at p. 292.

6o Immanuel Kant, The Metaphysics of Morals, transl. Mary J. Gregor, Immanuel Kant. Practical Philosophy (Cambridge: Cambridge University Press, 1996), pp. 472-7.

61 Ibid., p. 473.
} 
that I will be punished if I murder someone is saying nothing more than that I submit myself along with everyone else to the laws.'62

Punishing a criminal with the sole purpose of 'paying him back' is thus a sign of recognition of his status and dignity as an autonomous agent. Punishing a criminal therefore is a strict duty of public justice that his fellow citizens cannot discharge.

Even if a civil society were to dissolve itself by the consent of all its members (for example, if the people inhabiting an island decided to separate and disperse themselves throughout the world), the last murderer remaining in prison would first have to be executed, so that each has done to him what his deeds deserve and blood guilt does not cling to the people for not having insisted upon this punishment; for otherwise the people can be regarded as collaborators in this public violation of justice. ${ }^{63}$

This argument is flawed on a theoretical level as well as on the practical level of our institutions for punishment. On a theoretical level Kant seems to be in conflict with his argument in The Groundwork about the moral impermissibility of suicide. He argues there that if a person 'destroys himself in order to escape from a trying condition' he uses himself 'merely as a means to maintain a tolerable condition up to the end of life. ${ }^{\prime} 4$ Christine Korsgaard, one of the most respected Kant-scholars, interprets this argument by pointing out that 'the tolerable condition' that is pursued is only a 'good end' (or goal) 'because of the value conferred upon it by the choice of a rational being. However, by destroying the rational being, there is no 'good end' anymore, as the person for whom it is good does not exist any longer. ${ }^{65} \mathrm{It}$ is contradictory to destroy one's own life (and thereby one's autonomy) because that would amount to using oneself 'merely as a means'. In the same way we can argue that executing a murderer in order to respect his status as an autonomous, responsible agent, is contradictory. We then use him as a 'mere means' in order to express our respect. We aim to respect his autonomy by destroying his autonomy, which is inconsistent.

\footnotetext{
62 Ibid., p. 476.

63 Ibid., p. 474 .

64 Immanuel Kant, Groundwork of the Metaphysics of Morals, transl. Mary J. Gregor, Immanuel Kant. Practical Philosophy (Cambridge: Cambridge University Press, 1996), p. 8o.

65 Christine Korsgaard, The Sources of Normativity, (Cambridge: Cambridge University Press, 1996), p. 126.
} 
That punishment is justified because it constitutes the expression of respect for the agential dignity of the guilty criminal may be theoretically correct in cases other than the death-penalty. Yet, given the reality of our institutions of punishment the argument is as self-contradictory as is Kant's argument in favor of the execution of the murderer. Incarcerated offenders have to live in conditions that are meant to express disrespect of their agential dignity. The permanent control of their daily life not only infantalizes inmates, but the miserable conditions under which they live also 'serve to repeatedly remind them of their compromised moral status and stigmatized social role as prisoners' ${ }^{\prime} 6$ It is a travesty to think that incarceration is a form of respecting inmates' autonomy. One of the main characteristics of confinement in a 'total institution' like a prison is the loss of nearly all forms of self-determination and thereby the loss of the capacity of autonomy. ${ }^{67}$ Prisoners have to adjust to the paramount muting of self-initiative, as the prison institution not only determines daily routine but also takes over nearly all decisions for its inhabitants. What is more: prisons impose meticulous and continuous surveillance and apply a fine-graded system of punishments (and rewards) in order to discipline the behavior and thoughts of the inmates. Inhabitants of prisons are surrounded with such an extent network of enforceable regulations that inmates 'gradually lose the capacity to rely on internal organization and self-imposed personal limits to guide their actions' ${ }^{68}$ In practice the punishment of criminals in our society has nothing to do with respect for their agential dignity.

Evolution

There is one last argument for retaliation that must be mentioned, as it is often used in popular discussions despite its flawed nature. The argument is that most people have strong and persistent intuitions supporting the punishment of perpetrators with proportional harsh treatment. People want to punish the

66 U.S. Department of Health \& Human Services 2001, The Psychological Impact of Incarceration: Implications for Post-Prison Adjustment, (University of California, Santa Cruz). Available from: https://aspe.hhs.gov/basic-report/psychological-impact-incarceration-implications-post-prison-adjustment. [26 April 2017], p. 6.

67 ' $[\mathrm{T}]$ otal institutions disrupt or defile precisely those actions that in civil society have the role of attesting to the actor and those in his presence that he has some command over his world, that he is a person with 'adult' self-determination, autonomy, and freedom of action.' (Erving Goffman Asylums: Essays on the Social Situation of Mental Patients and Other Inmates (London: Doubleday \& Co, 1961): 47).

68 U.S. Department of Health and Human Services 2001, p. 5 . 
wrongdoer in order to give him his just desert rather than to achieve any future goal, like the prevention of future offenses through incapacitating the perpetrator or deterring potential villains. ${ }^{69}$ In concrete cases just desert for most people in most cultures is the primary sentencing motive. This is not because punishment satisfies people's feelings of revenge. Studies have shown that perpetrator punishment only partially, and moreover only transitorily, satisfies feelings of revenge. ${ }^{70}$ Moreover, people are willing to retaliate even if they know that on all counts it will cost them more than it will bring them, as is shown in the famous Ultimatum Game experiments. ${ }^{71}$ The explanation of this phenomenon is probably evolutionary. ${ }^{72}$ People have evolved a moral punishment instinct because it was adaptive in promoting cooperation. Punishment is used to get back free riders and deter future deserters. This is why people have an inborn tendency to punish. Punishment is associated with the activation of old, emotional regions of the brain. ${ }^{73}$ Even young children, including eight-month-old babies, punish. ${ }^{74}$ As a result of evolutionary developments the urge to punish has become part of our neural hardware.

The fact that retributivist intuitions are deeply grounded in our make-up as part of the evolutionary history of humans does not mean that such intuitions should be trusted and used to rationalize retributivism as a philosophy and practice. Prejudiced and tribal intuitions are also deeply ingrained impulses, probably resulting from evolutionary developments. ${ }^{75}$ As the Implicit Association Test shows, racist and sexist responses are deeply embedded in our minds (also among people of colour and among women) and can hardly be

69 John M. Darley, Kevin M. Carlsmith and Paul H. Robinson, 'Incapacitation and Just Deserts as Motives for Punishment', Law and Human Behavior, 24 (2000), 659-683.

70 Ulrich Orth, 'Does Perpetrator Punishment Satisfy Victims' Feelings of Revenge?', Aggressive Behavior, 30 (2004), 62-70. Kevin M Carlsmith, Timothy D. Wilson and Daniel T. Gilbert, 'The Paradoxical Consequences of Revenge', Journal of Personality and Social Psychology, 95 (2008), 1316-1324.

71 Werner Güth, Rolf Schmittberger and Bernd Schwarze, 'An Experimental Analysis of Ultimatum Bargaining', Journal of Economic Behavior \& Organization 3 (1982), 367-388. Alan G. Sanfey, James K. Rilling, Jessica A. Aronson, Leigh E. Nystrom and Jonathan D. Cohen, 'The Neural Basis of Economic Decision Making in Ultimatum Game', Science, 300 (2003), 1755-1757.

72 Jan-Willem van Prooijen, The Moral Punishment Instinct (Oxford: Oxford University Press, 2018).

73 Ibid., p. 13 .

74 J. Kiley Hamlin, Karen Wynn, Paul Bloom and Neha Mahajan, N., 'How Infants and Toddlers React to Antisocial Others', Proceedings of the National Academy of Sciences, 108 (2011), 19931-19936.

75 Jonathan Haidt, The Righteous Mind: Why Good People Are Divided by Politics and Religion, (New York: Pantheon, 2012). 
educated. ${ }^{76}$ People all over the world are prejudiced towards others based on group affiliations, be they racial, ethnic or religious. Research among monkeys suggest that the roosts of these prejudices lie deep in our evolutionary past. ${ }^{77}$ Even so, this does not mean that we can take such impulses to rationalize or justify racism or tribalism. Taking evolutionary results as an argument for justifying current human reactions or practices is a blatant fallacy. 'Is' never can ground 'ought' as far as evolution is concerned. Deeply ingrained as the retributivist urge may be, strong and persistent intuitive reactions and emotions can never, as such, be used to rationalize retributivism.

\section{Ideal Theories for a Non-Ideal World}

Thomas Noakes-Duncan ${ }^{78}$ has rightly noted that it was not so much criminologists or correctional experts who promoted retributivism in the 1970 (in criticism of the rehabilitative idealism of the early 19oos that saw criminals as patients in need of treatment). It was philosophers and jurists who promoted the retributivist agenda, like Andreas von Hirsch whose Report of the Committee for the Study of Incarceration (1976) - published under the title Doing Justice - was very influential. ${ }^{79}$

These scholars however formulated ideal theories, 'which tell us what aims and values a system of punishment must embody if it is to be unqualifiedly justified. ${ }^{80}$ Of course, no actual system will match the ideal and the question, therefore, is what the value is of the arguments with which retributivism is defended. Fair Play Theory may have some argumentative weight in case of some crimes like fraud or theft. But in a society where the benefits and advantages are not fairly distributed and in which offenders usually belong to the most disadvantaged groups, one can hardly say that offenders culpably take

76 Anthony Greenwald, Debby McGhee, Jordan Schwartz, J., 'Measuring Individual Differences in Implicit Cognition: The Implicit Association Test', Journal of Personality and Social Psychology, 74 (1998), 1464-1480.

77 Neha Mahajan, Margaret A. Martinez, Natashya L. Gutierrez, Gil Diesendruck, Mahzarin R. Banaji, and Laurie R. Santos, 'The Evolution of Intergroup Bias: Perceptions and Attitudes in Rhesus Macaques', Journal of Personality and Social Psychology, 100 (2011), 387-405.

78 Noakes-Duncan, Communities of Restoration, p. 41.

79 Andreas von Hirsch, Doing Justice: The Choice of Punishments - Report of the Committee for the Study of Incarceration, (Boston: Northeastern University Press, 1985).

8o Antony Duff and David Garland, 'Introduction' in A Reader on Punishment (Oxford: Oxford University Press, 1994), pp. 1-43, at 5 . 
an unfair advantage for themselves. Is justice done by punishing offenders in a society that is in itself deeply unjust? ${ }^{81}$

Even from a secular standpoint, it will be clear that a religious-Christian worldview that takes into account the essential imperfection of our world is a much more realistic starting point for thinking about justice. In a Christian view our world is broken and humankind suffers from the sin of selfishness and greed. This leads to structural injustices, between countries and within societies. Such a realism does not lead to pessimism though. From a religiousChristian point of view there is reason for hope (understood as the (interpersonal) process of imagining and anticipating a better future). For Christians God's eschatological promises of liberation may stimulate the hopeful imagination of a better future which may excite positive feelings of anticipation and the willingness to contribute to reform and transformation. ${ }^{82}$ This is the reason why religious pastors and Christian volunteers visit prisoners, support rehabilitation programs, serve victim support groups and strife to create the kind of cross-communal social networks needed to have opportunities of encounter so that trusting relationships may develop. ${ }^{83}$ The religious-Christian worldview is realistic but certainly not pessimistic about the 'condition humaine'.

Such a religious-Christian view accords better with a communitarian conception of society than the liberal conception from which retributivists start. In a liberal conception the focus is not so much on the interconnectedness of citizens, understood as social creatures who need each other. The focus is on the rights and liberties of citizens, understood as free, autonomous individuals who are capable of making choices for which they can be held accountable. According to this view personal dignity is grounded in the rational autonomy that individuals universally possess. However, such an idea of individual autonomy and dignity is an ideological fiction. It is an abstract idea that is not only psychologically untenable, it also suffers from serious sociological naivety. Personal dignity is a result of much more than the acknowledgment of rational autonomy, understood as the ability to make rational, moral choices as an agent who is not just a victim of his inclinations or incentives. ${ }^{84}$ People derive

81 Okeoghene Odudu, 'Retributivist Justice in an Unjust Society', Ratio Juris 16.3 (2003), 416-31.

82 Natascha Mueller-Hirth, 'Forgiveness and the Practice of Compromise in Post-apartheid South Africa', in John Brewer, Bernadette S. Hayes, Francis Teeney, Katrin Dudgeon, Nastascha Mueller-Hirth, and Shirley Lal Wijesinghe,The Sociology of Compromise after Conflict (London: Palgrave/MacMillan, 2018), pp. 103-128, at p. 127.

83 Mary Ann Cejka M. \& Thomas Bamat eds, Artisans of Peace: Grassroots Peacemaking Among Christian Communities (Mayknoll: Orbis, 2003).

84 Korsgaard, The Sources of Normativity, p. 165. 
their self-worth from particular acknowledgments in the various roles and identities they fulfill, as spouse, as parent, or as colleague. ${ }^{85}$ Social esteem is the main source of a sense of dignity and self-worth. ${ }^{86}$ What matters for social esteem is 'the recognition of particular qualities of individuals insofar as these qualities can be recognized as capacities and achievements that contribute to socially shared goals'. ${ }^{87}$ Restorative justice procedures are aimed at recognizing and promoting the dignity of victims and perpetrators, because restorative justice understands dignity and self-esteem as resulting from mutual acknowledgment in specific relationships. Restorative practices not only contribute to the dignity of the victim, but also to the dignity of the perpetrator, whose (life)-story is also heard and whose position as partner in a respectful dialogue is acknowledged.

Taking into account someone's messy life-story (and not just his abstract status as an autonomous agents) is of crucial importance given the sociological fact that people rarely live in ideal communities in which responsible individuals are bound together as equals who acknowledge rules that benefit everyone. Actual human societies are not like this at all. Most criminal offenders completely fail to correspond to the abstract picture that underlies the philosophical defenses of retributivism. Murphy ${ }^{88}$ cites one of the letters of Kant in which the philosopher himself seems to recognize this problem:

In a world of moral principle governed by God, punishments would be categorically necessary (insofar as transgressions occur). But in a world governed by men, the necessity of punishments is only hypothetical, and that direct union of the concept of transgression with the idea of deserving punishment serves the ruler only as a suggestion for what to do. ${ }^{89}$

By promoting a retributivist agenda - based on arguments for an ideal world - criminal justice policy in the real world has become deeply oppressive, as shown by slogans like 'Prison works', 'Adult time for adult crime', leading to

85 John Fischer, 'The Social Recognition of Human Dignity', International Journal of Bioethics, 21 (2010), 45-49, 45.

86 Axel Honneth, The Struggle for Recognition: The Moral Grammar of Social Conflicts, trans. Joel Anderson (Cambridge: Polity Press, 1996).

87 Timo Jütten, 'Dignity, Esteem, and Social Contribution: A Recognition-Theoretical View', The Journal of Political Philosophy, 25 (2017), 259-280, at 259.

88 Jeffrie G. Murphy, 'Kant's Theory of Criminal Punishment', in Jeffrie G. Murphy, Retribution, Justice and Therapy (Dordrecht: Reidel, 1979), pp. 82-91 at p. 86.

89 Immanuel Kant, 'Letter to J. B. Erhard, December 21, 1792', translated by Amulf Zweig in his Kant: Philosophical Correspondence, (Chicago: University of Chicago Press, 1967) p. 199 . 
a system of mass incarceration and systematic humiliation and infantilization of offenders.

\section{$9 \quad$ Mercy and Forgiveness}

Because human reality is messy, every human story is different and crime is not just a matter of 'making the wrong choice'. Crime has to be understood against the background of numerous social and psychological factors. From a Christian point of view justice therefore cannot be separated from mercy. As Marshall notes: '[c]ompassionate acceptance of human fallibility is essential to the functioning of healthy relationships. ${ }^{\prime 90}$ The restoration of healthy relationships is often better served by mercy than by retaliation. Christians regard retaliation and revenge as something to be countered in favour of moral indignation about crime combined with the persistent will to see and treat the offender as one's neighbor. Jesus, so Marshall argues, has set the retributive lex tallionis aside as a governing norm and has preached about what is needed to restore human dignity and human relations. ${ }^{91}$ Forgiveness is an ideal that Christians are called to put into practice wherever possible.

Retributivism has no place for the values of mercy or forgiveness. It sees mercy, understood as the 'remitting or mitigating of a burden of penalty to which the recipient would otherwise be liable' as infringement of the domain of justice. ${ }^{92}$ Forgiveness, understood as the overcoming of resentment and the bracketing off of guilt, is seen as morally bad, at least in cases of serious wrongs. Forgiveness is disqualified as a sign that the victim lacks sufficient respect for herself or does not take seriously the public wrong involved in breaking the law. ${ }^{93}$

Retributivists' aversion to mercy and forgiveness in the realm of criminal justice can be explained by reference to its abstract, non-relational picture of perpetrators and victims. Arguing that a failure to resent moral injuries done to me is a 'failure to care about the moral value incarnate in my own person' 94 ignores that people may find dignity and pride in being able to overcome their hostile feelings towards the wrongdoer. Holding that forgiveness and mercy cannot operate in the sphere of justice presupposes a specific conception of

$90 \quad$ Marshall, The Little Book of Biblical Justice, p. 37.

91 Marshall, Beyond Retributivism, p. 228.

92 Anthony Duff, 'The Intrusion of Mercy', Ohio State Journal of Criminal Law, 103 (2007), $361-387$, at p. 363 .

93 Murphy and Hampton, Forgiveness and Mercy, p. 18.

94 Ibid. 
justice instead of supporting such a conception. Restorative justice does not conceive forgiveness as a unilateral act of the victim, but underlines its relational character ${ }^{95}$ Restorative justice does not hold that being merciful contradicts the demands of penal justice, it holds that mercy may play a substantial role in penal justice.

What is then to be made about the complaint that mercy will always be unfair to those who do not receive it, because it discriminates between offenders whose penal desert is relevantly similar? ${ }^{96}$ According to restorative justice fairness is more than equity. It requires that one takes the life story and character of the perpetrator seriously in such a way that his condition may be seen as demanding a different response than in case of a seemingly similar offender. The objection that a liberal criminal law should respect an offender's privacy and avoid intruding into the deeper, more personal aspects of his life ${ }^{97}$ again favors a kind of formal role-playing in the court room and an abstraction from the real life of perpetrators. Restorative justice is critical of such abstractions and formalities.

We want to be clear, however, that we do not regard forgiveness as a moral requirement that can be imposed on victims. Forgiveness is always a supererogatory attitude and act, which may be inspired by a range of motives and considerations related to the particular situation of the victim, the particular situation of the perpetrator and the character of their encounter(s). Nor do we suggest that mercy or forgiveness should be unconditional. In restorative justice procedures the offender may be required to make amendments by compensating victims, apologizing, and performing community service. Forgiving is not condoning. If I forgive the wrongdoer I no longer hold it against him that he has wronged me. That does not mean that harms should not be repaired nor that I stop condemning and protesting against the kind of wrongdoing that I have experienced. ${ }^{98}$ Overcoming hostile feelings toward the offender does not imply that I stop hating the offence. Mercy and forgiveness involve an attitude of good will towards the wrongdoer, not towards the wrong done. Forgiveness is a relational attitude fostering reconciliation and restoration with the person. Of course, restoration of relationships may have its limits, for instance, when restoring the relationship would be dangerous to the forgiver (think of a battered wife and her abusive husband). Restorative justice does not preclude

95 Rodrigo Munoz, 'Justice and Mercy. Guilt, Punishment, and Forgiveness', Scripta Theologica, 48 (2016), 131-148.

96 Duff, 'The Intrusion of Mercy', p. 365 .

97 Ibid., p. 371.

98 Eve Garrard and David McNaughton, 'In Defense of Unconditional Forgiveness', Proceedings of the Aristotelian Society, 103 (2003), 29-6o at 47-9. 
that dangerous offenders are subject to crime prevention restraints. ${ }^{99}$ But such measures and limitations are not the result of a lack of concern for the wellbeing of the wrongdoer. An attitude of good will towards the wrongdoer can very well accompany a concern for safety of the victim and of the public in general.

The crucial difference between restorative justice and retributivism is the way the latter conceives of mercy and forgiveness as incompatible with criminal justice. Regarding mercy as an 'intrusion' into the sphere of justice, rather than as an aspect of the restoration that justice aims at, is morally dubious, so we contend. It conveys a seriously limited conception of what justice, also in the sphere of crime, involves. Restorative justice incorporates not just values like fairness and equity, but also reconciliation, forgiveness, dignity and rehabilitation. Such a conception of justice deserves full support and a fierce defense against its critics. Humility, forgiveness and reconciliation amounts to anything but a 'clumsy moral philosophy' in the realm of justice. Forgiveness and reconciliation are values in service of human dignity and peaceful social communities. Forgiveness and reconciliation serve the flourishing of human beings, which is the best kind of moral philosophy you can get. As Pumla Gobodo-Madikizela remarks in her discussion of a South-African mother who granted her son's murderer forgiveness: 'forgiveness.... is primarily concerned about giving human face to a man who is begging, not for the slate to be wiped clean, but for a chance to take the first steps towards rehabilitation and to live among fellow human beings.' ${ }^{100}$

We have analyzed the five main theories with which proponents of retributivism try to underpin their philosophy: they are Fair Play/ Trust theory, Kantian theory, Moral Communication theory, Vindication of Victims theory, and Evolutionary theory. We have seen that Fair Play, Kant and Evolution fail to justify punitive retribution of crime. We have argued that restorative justice procedures can do much better than retribution in serving the goals of Trust, Moral Communication and Victim Vindication.

Of course, restorative justice procedures, like victim-offenders encounters, are in practice less ideal and successful than the theory would like it to have.

99 Andrew Moss, Specifying Aims and Limits for Restorative Justice Models: A Reply to von Hirsch, Ashworth and Shearing, (Washington, DC: Prison Fellowship International, 2011).

100 Pumpla Gobodo-Madikizela, 'Trauma, Forgiveness and the Witnessing Dance: Making Public Spaces Intimate', The Journal of Analytical Psychology, 53: 2 (2008), 169-188, at 183. 
This is no argument in favour of retributivism, however, given that there is what Anthony Duff has called a 'gaping chasm' between the idea of what retributive justice ought to be and the existing penal practices. ${ }^{101}$ This gap between an ideal theory and non-ideal world provides support for a religious-Christian social philosophy and anthropology. We are convinced that many elements of the Christian view of the human condition, even in secular eyes, will be a serious competitor to the story of liberal secularism that underpins the retributivist philosophy.

101 Anthony Duff, 'Responsibility, Restoration, and Retribution', in Michael Tonry, ed, Retributivism Has a Past: Has It a Future? (Oxford, Oxford University Press, 2011), pp. 63-85 at p. 8 o. 